\title{
Protein-peptide composition in the lungs of rats with hyperhomocysteinemia
}

\author{
Nataliia Raksha, ${ }^{1}$ Tetiana Halenova, ${ }^{1}$ Tetiana Vovk, ${ }^{1}$ Olga Kharchenko, ${ }^{1}$ Oleksiy Savchuk, ${ }^{1}$ \\ Inga Samborska, ${ }^{2}$ Nataliia Zaichko, ${ }^{2}$ Ludmila Ostapchenko, ${ }^{1}$ Oleksandr Maievskyi ${ }^{1}$ \\ ${ }^{1}$ Educational and Scientific Center "Institute of Biology and Medicine" of Taras Shevchenko National University of \\ Kyiv, Kyiv; ${ }^{2}$ National Pirogov Memorial Medical University, Vinnytsia, Ukraine
}

\begin{abstract}
The accumulated data indicate that a high level of homocysteine may be a central pathogenetic factor of chronic obstructive pulmonary disease. In this study, we investigated the effect of hyperhomocysteinemia (HM) on protein homeostasis in the rat lungs. The level of proteins, peptides, total proteolytic activity, as well as protein-peptide composition, were evaluated. HM was induced by daily intragastric administration of DL-homocysteine thiolactone $\left(100 \mathrm{mg} \cdot \mathrm{kg}^{-1}\right.$ of body weight) to albino non-linear male rats for 28 days. Twelve hours after the last administration, the rats were sacrificed and the lungs were harvested. Our findings showed that HM caused the disturbances in the protein homeostasis in the lungs that are manifested by a decrease in the
\end{abstract}

Correspondence: Nataliia Raksha, ESC "Institute of Biology and Medicine" of Taras Shevchenko National University of Kyiv, Volodymyrska Str. 64/13, 01601, Kyiv, Ukraine

Tel.: +380666246019

E-mail: nkudina@ukr.net

Key words: Protein homeostasis; lungs; hyperhomocysteinemia.

Contributions: NR: data interpretation and manuscript review. TH: carried out the experiments. TV and OK: carried out the experiments. OS and NZ: experimental design. IS: statistical analysis. LO and OM: supervised the study.

Conflict of interest: The authors have no conflicts of interest to declare.

Ethics approval: All experiments on animals were performed in the compliance with international principles of the European Convention for the protection of vertebrate animals used for experimental and other scientific purposes (Strasbourg, 1986). The study was approved by the Ethical Committee of Taras Shevchenko National University of Kyiv.

Received for publication: 16 May 2021.

Revision received: 1 July 2021

Accepted for publication: 20 August 2021.

${ }^{\circ}$ Copyright: the Author(s), 2021

Licensee PAGEPress, Italy

Journal of Biological Research 2021; 94:9858

doi:10.4081/jbr.2021.9858

This article is distributed under the terms of the Creative Commons Attribution Noncommercial License (by-nc 4.0) which permits any noncommercial use, distribution, and reproduction in any medium, provided the original author(s) and source are credited. level of proteins in the young and old animals and an increase in the level of peptides in the rats of all studied groups. We found a change in the protein composition in the lung of HM rats - a decrease in the level of proteins with a molecular weight of 50 $\mathrm{kDa}$ to $100 \mathrm{kDa}$ simultaneously with an increase in the level of proteins with a molecular weight of less than $50 \mathrm{kDa}$. Despite the fact that the peptide profile was the same in both control animals and HM animals, the level of individual peptide fractions increased significantly in the rats with HM. Obtained data could contribute to explain, at least in part, the mechanisms involved in the pathogenesis of lung damage in HM.

\section{Introduction}

Protein homeostasis, which means the balanced synthesis of new proteins and timely degradation of misfolded, damaged, or old proteins are recognized to play an important role in maintaining overall metabolism. Any disorders of protein homeostasis can potentially lead to pathological consequences. On the other hand, alteration of protein profile in the tissue may reflect the progression of the disease. Therefore, a detailed study of the protein composition of tissues is of great importance for monitoring the state of the disease and evaluating the effectiveness of the treatment. ${ }^{1}$ The total amount of peptides present in biological fluids and tissues is considered as the peptide pools. The peptide pool of each organ is very specific in composition and individual peptide content. This is due to the set of proteolytic enzymes, their regulators, and the composition of substrate proteins, which differ slightly for different organs. Recently, the understanding of the role of peptide pools as an integral part of the mechanisms involved in the regulation and maintenance of tissue hemostasis has expanded significantly. According to modern concepts, peptide pools have a modulating effect on the nervous, endocrine, immune and cardiovascular systems. . $^{2,3}$

Peptides can influence the rate of biochemical processes and determine the direction of the metabolic pathways in organs. Peptides in pools are either derived from protein precursors as a result of their processing, or are degradation products of tissue proteins. Therefore, both the composition of peptides and the level of individual peptides are partially determined by the rate of proteolysis. It is considered that diseases associated with an increase in the activity of proteolytic enzymes are accompanied by the alteration in the peptide pools. Moreover, changes in the qualitative and quantitative composition of peptide pools are not only the result of metabolic disorders but can also lead to further complications under the pathological process. At present, a lot of scientific efforts are aimed at studying how Hyperhomocysteinemia (HM) affects various organs, leading to 
the development of systemic disorders. Despite the importance of the lungs as a vital organ, the possible mechanisms underlying the effect of HM on lung function are not fully understood. Since, to our knowledge, there are no researches that demonstrate any association between HM and protein homeostasis in the lungs, this study evaluates the effect of HM on protein-peptide composition in the lungs of rats with HM.

\section{Materials and Methods}

\section{Reagents}

Thiolactone D,L-homocysteine, tris(hydroxymethyl)aminomethane, sodium dodecyl sulfate, Coomassie Blue R-250, acrylamide, N,N'-methylenebisacrylamide were purchased from Sigma-Aldrich (St. Louis, MO, USA). All other chemicals and reagents used in this study were of analytical grade quality and available commercially.

\section{Animals and experimental design}

A total of 60 albino non-linear male rats were used in the study. All experiments on animals were performed in the compliance with international principles of the European Convention for the protection of vertebrate animals used for experimental and other scientific purposes (Strasbourg, 1986). The study was approved by the Ethical Committee of Taras Shevchenko National University of Kyiv. The experiments were started after 7 days of animal acclimation in the animal facility of Taras Shevchenko National University of Kyiv, maintained under constant conditions of temperature $\left(22 \pm 3{ }^{\circ} \mathrm{C}\right)$, humidity $(60 \pm 5 \%)$, and light (12 h light/12 h dark cycle). Standard rodent food and water were provided ad libitum. The animals of different ages were used in the current study - one-month-old rats that are corresponded to young animals; six-month-old rats that are corresponded to adult animals, and twenty-month-old rats that are corresponded to old animals. HM was induced by intragastric administration of DL-homocysteine thiolactone diluted in $1 \%$ starch solution ( $100 \mathrm{mg} \cdot \mathrm{kg}^{-1}$ of body weight), ones per day for 28 days. ${ }^{4}$ The control rats were received an equal volume of $1 \%$ starch. HM development was confirmed by the high blood level of homocysteine (more than $15 \mu \mathrm{mol} \cdot \mathrm{L}^{-1}$ ). The level of homocysteine in the blood plasma was determined by enzyme-linked immunosorbent assay using the kit «Homocysteine EIA» (AxisShield, UK). On the 29th day since the start of the experiment, the animals were sacrificed.

Thus, there were 3 experimental groups each of them consists of the control rats (ten animals) and the rats with HM (ten animals): i) Group \#1 (young animals); ii) Group \#2 (adult animals); and iii) Group \#3 (old animals).

\section{Lung sample preparation}

The lungs were immediately collected after the animals have being sacrificed. The tissue $(1 \mathrm{~g})$ was homogenized in $9 \mathrm{~mL}$ icecold $50 \mathrm{mM}$ Tris- $\mathrm{HCl}$ buffer ( $\mathrm{pH}$ 7.4). The homogenate solution was centrifuged at $5000 \mathrm{~g}$ for $15 \mathrm{~min}$ at $4^{\circ} \mathrm{C}$. The pellet was discarded and the supernatant was immediately separated and used for the measurements. The protein concentration was determined by the Bradford method using crystalline bovine serum albumin as a standard. ${ }^{5}$

\section{Peptide pool isolation}

The peptide pool was obtained according to Nykolaychyk et $a l .{ }^{6}$ The plasma samples were mixed with $1.2 \mathrm{M} \mathrm{HClO}_{4}$ at $1: 1$ $(\mathrm{v} / \mathrm{v})$ ratio in order to precipitate the proteins. After centrifugation at $10000 \mathrm{~g}$ for $20 \mathrm{~min}$ at $4^{\circ} \mathrm{C}$ the supernatants were neutralized by $5 \mathrm{M} \mathrm{KOH}$ to $\mathrm{pH} 7.0$ and the samples were subjected to centrifugation step again. After ethanol was added to the final concentration of $80 \%$, the samples were kept at $4{ }^{\circ} \mathrm{C}$ for $30 \mathrm{~min}$ and centrifuged. The optical density of the supernatants was determined with a spectrophotometer Smart SpecTMPlus (BioRad, USA) at $210 \mathrm{~nm}$. The concentration of peptides was calculated using calibration curve prepared with CBZ-glycilglycine dipeptide of $0.26 \mathrm{kDa}$ as a standard.

\section{Analysis of peptide pool by size-exclusion chromatography}

The peptide pools were analyzed by size exclusion chromatography on Sephadex G 15 column (Bio Rad, USA) pre-equilibrated with $0.05 \mathrm{M}$ Tris- $\mathrm{HCl}, \mathrm{pH} 7.4$ containing $0.13 \mathrm{M} \mathrm{NaCl}^{7}$ The samples were loaded and the corresponding peaks were collected at a flow rate of $30 \mathrm{~mL}$ per hour. The areas under the peaks of chromatographic curves were calculated using the OriginLab (v 9.1). The molecular weight of peptides was estimated using calibration curve. For this purpose, the column was previously calibrated with standard marker solution containing of lysozyme $(14.3 \mathrm{kD})$, insulin $(5.7 \mathrm{kDa})$, and vitamin B12 (1.35 kDa).

\section{Sodium dodecyl sulfate polyacrylamide gel electrophoresis (SDS-PAGE)}

SDS-PAGE was carried out using $4 \%(\mathrm{w} / \mathrm{v})$ stacking gel and $10 \%(\mathrm{w} / \mathrm{v})$ separating gel. ${ }^{8}$ SDS-PAGE was performed using MiniProtean Tetra System (Bio Rad, USA) at $19 \mathrm{~mA}$ for stacking and $36 \mathrm{~mA}$ for separating gels. Samples were prepared by mixing with sample buffer (0.05 M Tris-HCl, $\mathrm{pH} 8.8,2 \% \mathrm{SDS}, 5 \%$ sucrose, and $0.02 \%$ bromophenol blue) at the ratio of $1: 1(\mathrm{v} / \mathrm{v})$. Samples were heated at $95^{\circ} \mathrm{C}$ for $1 \mathrm{~min}$ prior loading in gel. The total amount of proteins applied per well of gel was $20 \mu \mathrm{g}$. The gels were stained with $2.5 \%$ Coomassie brilliant blue R-250 in $10 \%$ (v/v) ethanol, $10 \%(\mathrm{v} / \mathrm{v})$ acetic acid, $15 \%(\mathrm{v} / \mathrm{v})$ isopropanol and the background of the gel was destained with $7 \%(\mathrm{v} / \mathrm{v})$ acetic acid for $30 \mathrm{~min}$. Apparent molecular weights of proteins were estimated using protein calibration mixture (Bio Rad, USA).

\section{Determination of total proteolytic activity}

Total proteolytic activity was measured using casein as a substrate according to the method by Munilla-Moran and Stark. ${ }^{9}$ Casein $(2 \%)$ in $50 \mathrm{mM}$ Tris- $\mathrm{HCl}$ buffer $(\mathrm{pH} 7.4)$ containing 0.13 $\mathrm{M} \mathrm{NaCl}$ was incubated in the presence of tested sample $(50 \mu \mathrm{g}$ of total protein) at $37^{\circ} \mathrm{C}$ for $30 \mathrm{~min}$. The reaction was stopped by addition of trichloroacetic acid (7\%) and the sample was stand for $15 \mathrm{~min}$ at $4{ }^{\circ} \mathrm{C}$. The mixture was centrifuged at $15,000 \mathrm{~g}$ for $30 \mathrm{~min}$. The absorbance of the supernatant was measured spectrophotometrically (SmartSpecPlus, Bio Rad, USA) at $280 \mathrm{~nm}$ against the blank in which tested sample was substituted by corresponding volume of $50 \mathrm{mM}$ Tris- $\mathrm{HCl}$ buffer ( $\mathrm{pH}$ 7.4) containing $0.13 \mathrm{M} \mathrm{NaCl}$. Total proteolytic activity was expressed as rel. units $\cdot \mathrm{g}^{-1}$ of lung tissue.

\section{Statistical analysis}

The data of biochemical estimations were reported as mean \pm SEM for each group $(n=10)$. Statistical analyses were performed 
using one-way analysis of variance (ANOVA). Differences were considered to be statistically significant when $\mathrm{p}<0.05$.

\section{Results and Discussion}

At the first stage, the level of proteins in the lungs of the rats with HM was estimated. A stable level of proteins in the lungs is vital to ensure their proper functional activity. On the other hand, abnormal protein homeostasis, manifested by changes in protein content, is considered a key pathogenic mechanism in almost all lung diseases. ${ }^{10}$ As can be seen from Table 1, the level of proteins in the HM rats of Group \#1, which included young animals, was reduced by half compared with the corresponding control animals. In the rats of Group \#2, no alterations in the protein level were found. The level of proteins in the lungs of old animals with HM (Group \#3) was also decreased, but the change in this parameter was not as pronounced as in the case of the rats of Group \#1. The reduced protein levels in the lung of the rats with HM may be partly due to the enhancement of proteolysis. Clinical data indicate the contribution of proteolytic imbalance to the progression of HMrelated disorders. ${ }^{11,12}$ It has been shown that HM induces systemic oxidative stress, leading to the formation of Reactive Oxygen Species (ROS). ${ }^{13}$ Mild ROS accumulation can transiently enhance proteolysis via direct influence on the ubiquitin-proteasome system and induction of autophagy. In addition, ROS are able to nonenzymatically modify proteins, thus directing them to the pathway of proteolytic degradation. ${ }^{14,15}$ It should be noted that the total protein level in the lungs of control animals did not change with age and remained within the range of 30-35 $\mathrm{mg}$ per $\mathrm{g}$ of tissue.

Although the level of protein in the lungs of the control animals of all groups is the same, the protein composition can change with age. In addition, HM may be a factor that affects the protein profile in the tissue. To address this point, the elec- trophoretic analysis of the lung tissue was performed. The main goal was to find alterations in the protein composition, which may reflect HM-induced disorders of protein homeostasis. Taking into account the obtained data (Figure 1), it can be assumed that aging is accompanied by the redistribution of proteins of different molecular weights.

As follows from Table 2, the percentage of proteins with molecular weights of $70-100 \mathrm{kDa}$ was $3.8 \%, 16.9 \%$, and $17.3 \%$ for the control animals of Group \#1, \#2, and \#3, respectively. At the same time, the level of proteins with a molecular weight of less than 30 $\mathrm{kDa}$ decreased with age and was $56.5 \%$ for young animals (Group \#1); $43.2 \%$ for adult animals (Group \#2), and 36.1\% for aged animals. According to the data, the pathogenesis of HM was accompanied by the decrease in the level of proteins with a molecular weight from $50 \mathrm{kDa}$ to $100 \mathrm{kDa}$, simultaneously with the increase in the level of proteins with a molecular weight of less than $50 \mathrm{kDa}$. More pronounced changes in the protein composition were found in the lungs of rats of Group \#1 - the level of 100-150 kDa proteins decreased 4.1 times; the level of 70-100 kDa proteins decreased 16.6 times while the level of $30-50 \mathrm{kDa}$ proteins increased 11 times compared with the corresponding controls. Given the importance of protein homeostasis in maintaining proper lung function, disturbances in the ratio of proteins of different molecular weights may be a factor implicated in HM-mediated lung diseases.

According to the concept of a "tissue-specific peptide pool," the sum of all peptides in the tissue is considered as the peptide pool that is involved in the maintenance of homeostasis within the organs. Despite the sufficient stability of the peptide pools, both the level of peptides and their repertoire can undergo changes under the pathological process. Moreover, the changes in the peptide pool are considered to be one of the factors of homeostasis disorder in response to disease progression. On the other hand, due to a wide range of activities ${ }^{2,3}$ peptides can participate in tissue repair. In view of all of the above, the peptide pools from the lungs of the rats were isolated and analyzed.

Table 1. Level of the proteins and peptides in the lungs of rats with hyperhomocysteinemia.

\begin{tabular}{llcc} 
& & Level of proteins, $\mathrm{mg}$ per $\mathrm{g}$ of tissue & Level of peptides, rel. units per g of tissue \\
Group \#1 & Control & $32.4 \pm 1.5$ & $3.22 \pm 0.15$ \\
& HM & $15.7 \pm 0.6^{*}$ & $5.54 \pm 0.21^{*}$ \\
Group \#2 & Control & $34.1 \pm 1.6$ & $4.93 \pm 0.21$ \\
& HM & $35.7 \pm 1.5$ & $9.90 \pm 0.47^{* *}$ \\
\hline Group \#3 & Control & $30.5 \pm 1.1$ & $5.23 \pm 0.25$ \\
& HM & $25.7 \pm 1.2^{* * *}$ & $11.87 \pm 0.58^{* * *}$ \\
\hline
\end{tabular}

Values are expressed as mean $\pm \operatorname{SEM}(\mathrm{n}=10) ;{ }^{*} \mathrm{p}<0.05$ significantly different from the control of Group $\# 1 ; * * \mathrm{p}<0.05$ significantly different from the control of Group \#2; $* * * \mathrm{p}<0.05$ significantly different from the control of Group \#3.

Table 2. Results of electrophoretic analysis of the protein composition in the lungs of rats with hyperhomocysteinemia.

\begin{tabular}{|c|c|c|c|c|c|c|}
\hline \multirow[t]{2}{*}{ Molecular weight } & \multicolumn{2}{|c|}{ Group \#1 } & \multicolumn{2}{|c|}{ Group \#2 } & \multicolumn{2}{|c|}{ Group \#3 } \\
\hline & Control & HM & Control & HM & Control & HM \\
\hline$>150 \mathrm{kDa}$ & - & - & - & - & - & - \\
\hline $150-100 \mathrm{kDa}$ & $20.7 \pm 1.05$ & $5.0 \pm 0.20^{*}$ & $20.3 \pm 1.00$ & $14.1 \pm 0.65^{* *}$ & $25.1 \pm 1.25$ & $12.7 \pm 0.60 * * *$ \\
\hline $100-70 \mathrm{kDa}$ & $3.8 \pm 0.20$ & $0.2 \pm 0.01^{*}$ & $16.9 \pm 0.75$ & $10.3 \pm 0.50^{* *}$ & $17.3 \pm 0.80$ & $9.1 \pm 0.45^{* * *}$ \\
\hline $70-50 \mathrm{kDa}$ & $17.0 \pm 0.85$ & $0.8 \pm 0.04^{*}$ & $16.3 \pm 0.75$ & $0.2 \pm 0.01^{* *}$ & $13.4 \pm 0.35$ & $0.3 \pm 0.01 * * *$ \\
\hline $50-30 \mathrm{kDa}$ & $1.8 \pm 0.07$ & $20.6 \pm 0.95^{*}$ & $3.2 \pm 0.16$ & $10.0 \pm 0.55^{* *}$ & $7.9 \pm 0.45$ & $13.3 \pm 0.40 * * *$ \\
\hline $30 \mathrm{kDa}$ & $56.5 \pm 2.50$ & $73.2 \pm 3.70^{*}$ & $43.2 \pm 2.10$ & $65.1 \pm 3.25^{* *}$ & $36.1 \pm 1.50$ & $64.3 \pm 3.00^{* * *}$ \\
\hline
\end{tabular}

Values are expressed as mean $\pm \mathrm{SEM}(\mathrm{n}=10) ;{ }^{*} \mathrm{p}<0.05$ significantly different from the control of Group $\# 1 ;{ }^{* *} \mathrm{p}<0.05$ significantly different from the control of Group $\# 2 ;{ }^{* * *} \mathrm{p}<0.05$ significantly different from the control of Group \#3. 
At first, the level of peptides was determined. Our data revealed an increase in the level of peptides in the lungs of all studied groups (Table 1). The level of peptides increased 1.7 times, 2 times, and 2.2 times, respectively, for the HM rats of Group \#1, \#2, and \#3. It should be noted, the level of peptides in the lungs of control animals was gradually increased with age and was found at the level of 3.22 rel. units per $\mathrm{g}$ of tissue for the control rats of Group \#1; 4.93 rel. units per $g$ of tissue for the control rats of Group \#2; and 5.23 rel. units per $g$ of tissue for the control rats of Group \#3.

Next, the peptide pools were analyzed by size exclusion chromatography. As can be seen from Table 3, the peptide pools in the lungs of both control animals and animals with HM were represented by four main fractions of peptides, the molecular weight of which was $2147 \mathrm{Da} ; 1781 \mathrm{Da} ; 1308 \mathrm{Da}$, and $827 \mathrm{Da}$. No differences in the molecular weight of peptides in the lungs of control animals and animals with HM were found. The level of pep- tides with a molecular weight of $1781 \mathrm{Da}$ and $1308 \mathrm{Da}$ increased with age while the level of 2147 Da peptides and the level of 827 Da did not change statistically. The most pronounced changes in the peptide levels were found in the group of young rats (Group \#1). The level of peptides with a molecular weight of $1781 \mathrm{Da}$, $1308 \mathrm{Da}$, and $827 \mathrm{Da}$ increased 4.84 times, 2.21 times, and 1.5 times compared with the corresponding controls. The absence of peptides with molecular weight other than the control values makes it impossible to speak of an increase in catabolism. The obtained results can be explained, first of all, by the activation of canonical proteolytic enzymes.

Therefore, we assessed the total proteolytic activity in the lungs of HM rats. In this assay, casein was used as a substrate, which allowed to estimate the overall proteolytic activity. The obtained results showed an increase in this parameter in the rats of all studied groups (Table 4).

Table 3. Results of chromatographic analysis of the peptide pool derived from the lungs of rats with hyperhomocysteinemia.

\begin{tabular}{|c|c|c|c|c|c|c|}
\hline \multirow{2}{*}{ Molecular weight } & \multicolumn{2}{|c|}{ Group \#1 } & \multicolumn{2}{|c|}{ Group \#2 } & \multicolumn{2}{|c|}{ Group \#3 } \\
\hline & Control & HM & Control & HM & Control & HM \\
\hline \multicolumn{7}{|c|}{ Area under peak (r.u) } \\
\hline $2147 \mathrm{Da}$ & 0.088 & 0.070 & 0.086 & 0.089 & 0.086 & 0.106 \\
\hline $1781 \mathrm{Da}$ & 0.033 & 0.160 & 0.061 & 0.064 & 0.073 & 0.085 \\
\hline $1308 \mathrm{Da}$ & 0.051 & 0.113 & 0.119 & 0.127 & 0.123 & 0.146 \\
\hline $827 \mathrm{Da}$ & 0.012 & 0.018 & 0.017 & 0.020 & 0.019 & 0.035 \\
\hline
\end{tabular}

Values are expressed as mean \pm SEM $(\mathrm{n}=10)$.

Table 4. Total proteolytic activity in the lungs of rats with hyperhomocysteinemia.

\begin{tabular}{|c|c|c|c|c|c|}
\hline \multicolumn{2}{|c|}{ Group \#1 } & \multicolumn{2}{|c|}{$\begin{array}{l}\text { Group \#2 } \\
\text { rel. units.g-1 of tissue }\end{array}$} & \multicolumn{2}{|c|}{ Group \#3 } \\
\hline Control & HM & Control & HM & Control & HM \\
\hline $9.21 \pm 0.04$ & $12.93 \pm 0.06^{*}$ & $12.54 \pm 0.004$ & $18.44 \pm 0.03^{* *}$ & $7.46 \pm 0.05$ & $10.77 \pm 0.04$ \\
\hline
\end{tabular}

Values are expressed as mean \pm SEM $(n=10) ;{ }^{*} \mathrm{p}<0.05$ significantly different from the control of Group \#1; ${ }^{* *} \mathrm{p}<0.05$ significantly different from the control of Group \#2; ${ }^{* * *} \mathrm{p}<0.05$ significantly different from the control of Group \#3.
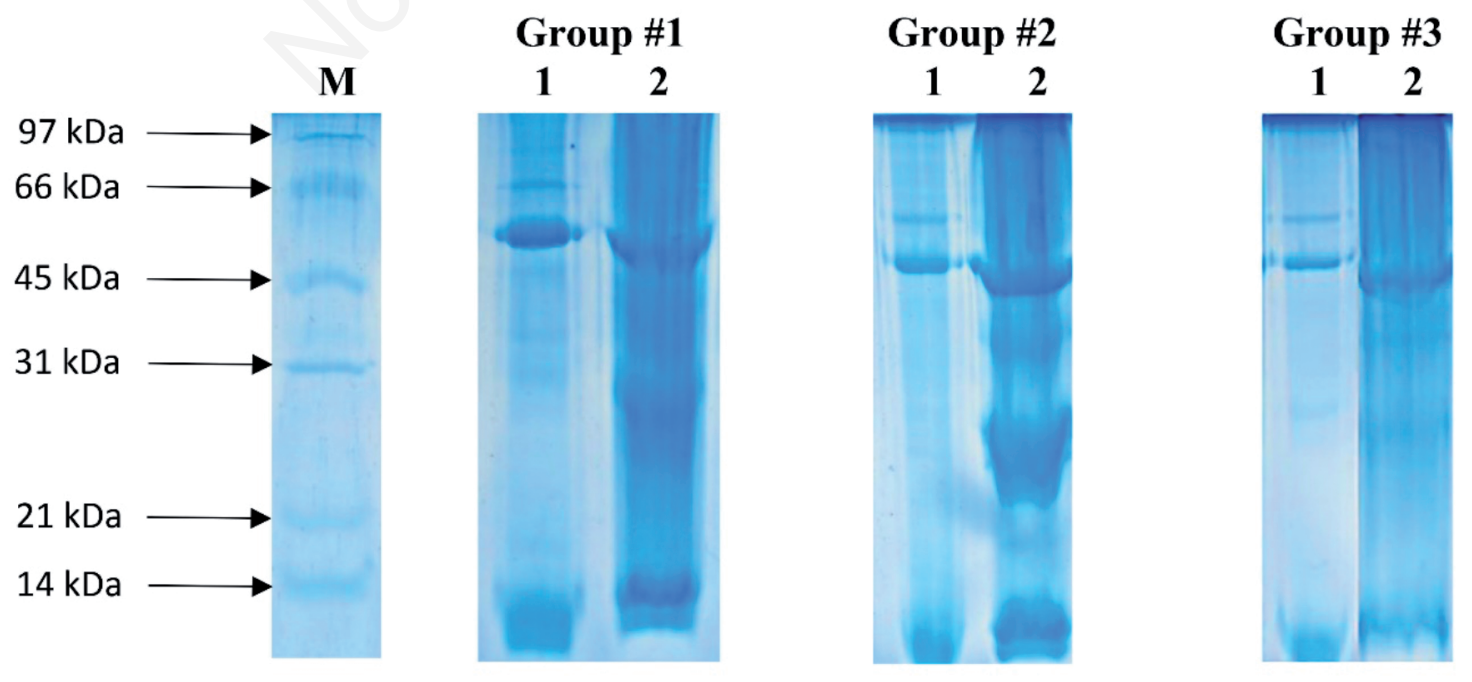

Figure 1. SDS-PAGE electropherogram of the lung tissue of the rats: M - molecular weight markers; 1 - the control animals; 2 - the animals with hyperhomocysteinemia. 
The total proteolytic activity increased by 1.40 -fold, 1.47 fold, and 1.44-fold in the lungs of HM rats of Group \#1, Group $\# 2$, and Group \#3, respectively. Obtained data are in agreement with other studies showing that pathological level of homocysteine affects the proteolytic potential. ${ }^{11,12}$

\section{Conclusions}

In conclusion, HM leads to disturbances in the protein homeostasis in the lungs of rats that are manifested by a decrease in the level of proteins in the young and old animals as well as an increase in the level of peptides in the rats of all studied groups. We found changes in the protein composition in the lung of HM rats - a decrease in the level of proteins with a molecular weight of $50 \mathrm{kDa}$ to $100 \mathrm{kDa}$ simultaneously with an increase in the level of proteins with a molecular weight of less than $50 \mathrm{kDa}$. Despite the fact that the peptide profile was the same in both control animals and HM animals, the level of individual peptide molecules increased significantly in the rats with HM. Thus, the disturbance in the protein-peptide composition may play an important role in the pathogenesis of pulmonary damage caused by HM. Obtained data could contribute to explain, at least in part, the mechanisms involved in the pathogenesis of lung damage.

\section{References}

1. Ivanov VT, Yatskin ON, Kalinina OA, et al., Tissue-specific peptide pools. Generation and function. Pure Appl Chem 2000;72:355-63.

2. Karelin AA, Blishchenko EYu, Ivanov VT. A novel system of peptidergic regulation. FEBS Lett 1998;428:7-12.

3. Yatskin ON, Karelin AA, Ivanov VT. Peptidomes of the brain, heart, lung, and spleen of a rat: Similarity and differences. Russian J Bioorgan Chem 2009;35:426-36.
4. Stangl G, Weisse K, Dinger C, et al. Homocysteine thiolactone-induced hyperhomocysteinemia does not alter concentrations of cholesterol and SREBP-2 target gene mRNAS in rats. Exp Biol Med (Maywood) 2007;232:81-7.

5. Bradford MM. A rapid and sensitive method for quantities of utilizing the principle of protein binding. Anal Biochem 1976;86:193-200.

6. Nykolaychyk BB, Moyn VM, Kyrkovskyy VV. Method for determining of the peptide pool molecular. Lab Case 1991;10:13-8.

7. Hong P, Koza S, Bouvier ESP. Size-exclusion chromatography for the analysis of protein biotherapeutics and their aggregates. J Liq Chromatogr Relat Technol 2012;35:292350 .

8. Laemmli U. Cleavage of structural proteins during the assembly of the head of bacteriophage T4. Nature 1970;227:680 85.

9. Munilla-Moran R, Stark JR. Protein digestion in early turbot larvae, Scophthalmus maximus (L.). Aquaculture 1989;8:315-327.

10. Meiners S, Greene CM. Protein quality control in lung disease: it's all about cloud networking. Eur Respir J 2014;44:846-9.

11. Bescond A, Augier T, Chareyre C, et al. Influence of homocysteine on matrix metalloproteinase-2: activation and activity. Biochem Biophys Res Commun 1999;263:498-503.

12. Chaussalet M, Lamy E, Foucault-Bertaud A, et al. Homocysteine modulates the proteolytic potential of human vascular endothelial cells. Biochem Biophys Res Commun 2004;316:170-6.

13. da Cunha AA, Ferreira AGK, da Cunha MJ, et al. Chronic hyperhomocysteinemia induces oxidative damage in the rat lung. Mol Cell Biochem 2011;358:153-60.

14. Friguet B. Oxidized protein degradation and repair in ageing and oxidative stress. FEBS Letters 2006;580:2910-16.

15. Lai Ch-Hu, Lee Ch-N, Bai K-J, et al. Protein oxidation and degradation caused by particulate matter. Scientific Reports $2016 ; 6: 33727$. 